P. G. WATSON AND D. GAIRDNER: TRIC AGENT AS A CAUSE OF NEONATAL EYE SEPSIS
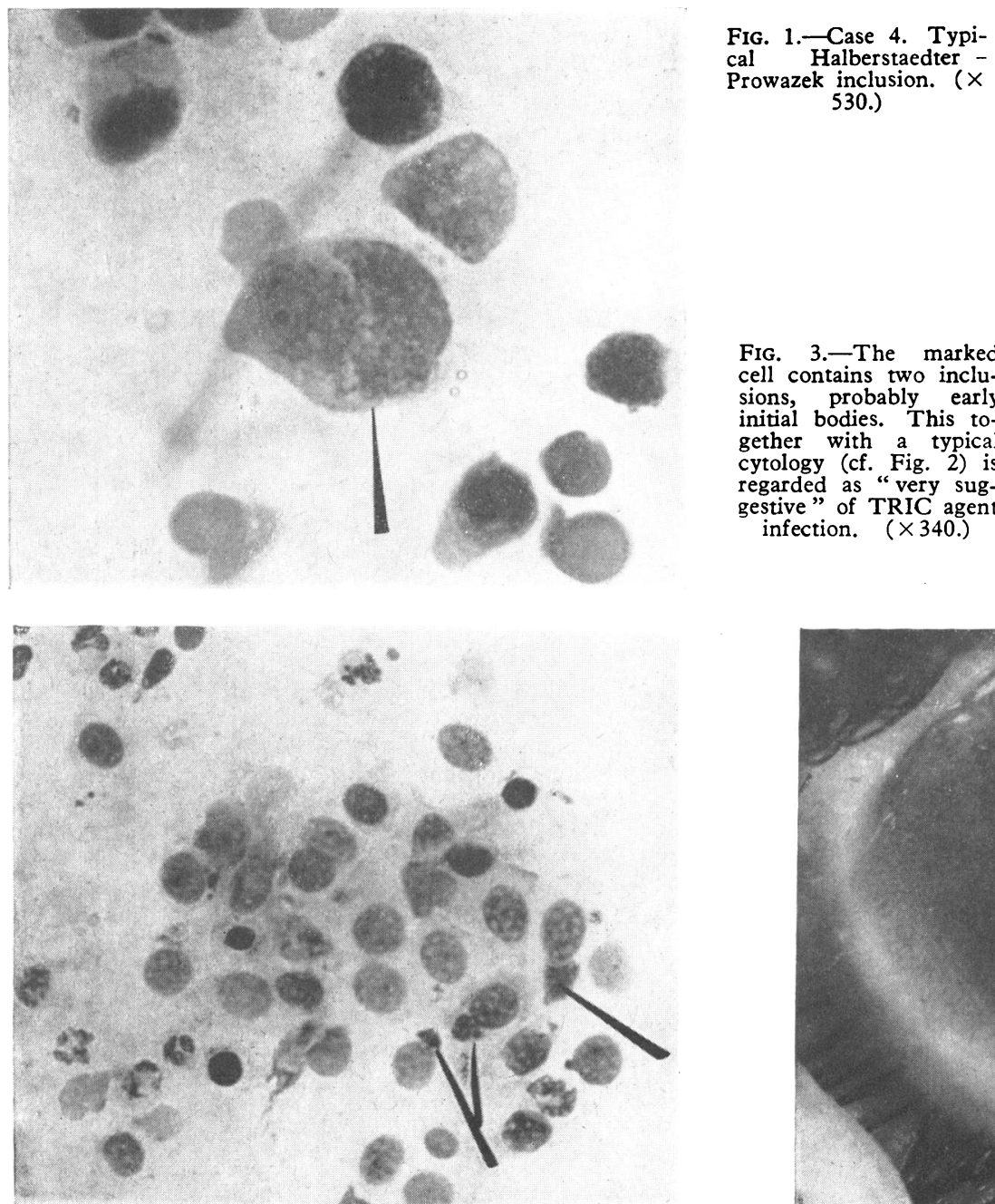
Fig. 3.-The marked cell contains two inclu- sions, probably early initial bodies. This to- gether with a typical cytology (cf. Fig. 2) is regarded as "very sug- restive" af "TRIC sug- infection. $(\times 340$. $)$

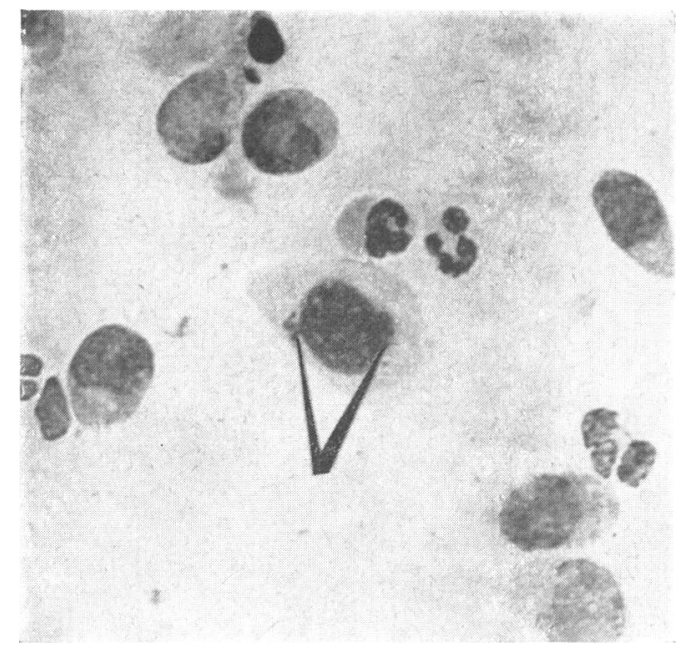

FIg. 2.-Case 1. Cytology typical of TRIC agent infection with polymorphs, lymphocytes, monocytes, and degenerate epithelial cells. Three Halberstaedter-Prowazek inclusions indicated. $(\times 205$.

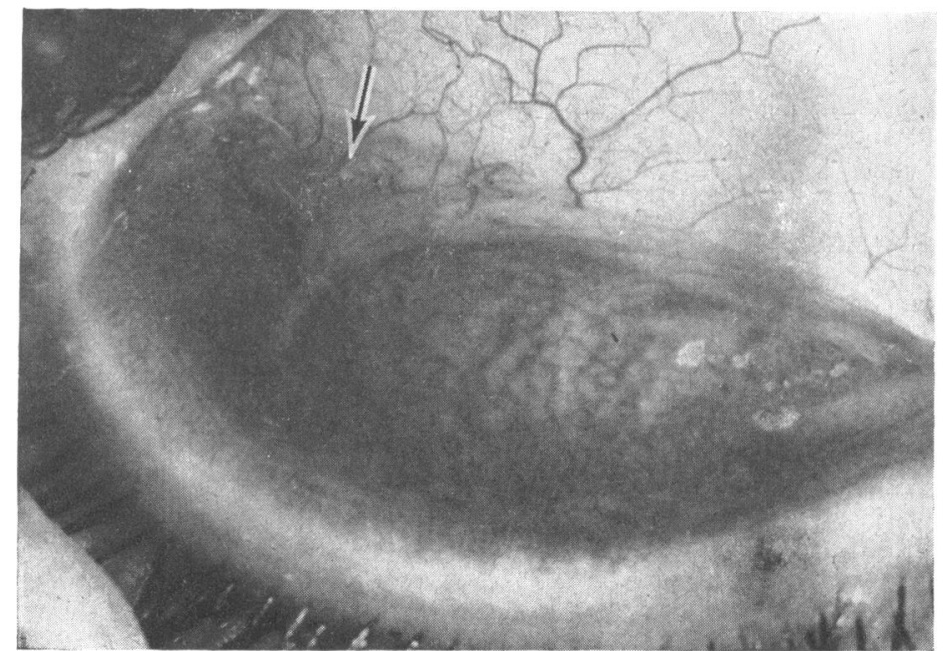

Fig. 4.-Case 5. A "sheet" scar of the conjunctiva of the lower fornix, forming a fold from bulbar to fornix conjunctiva.

I. N. MARKS AND A. D. KEET: INTRAMURAL RUPTURE OF THE OESOPHAGUS

Fig. 1. - Radiograph showing collection of barium outside lumen of the oesophagus just above leve of diaphragm.

FIG. 2. - Radiograph showing band-like longitudinal intraluminal filling defects in oesophagus. Note extraluminal collection of barium just above level of diaphragm.

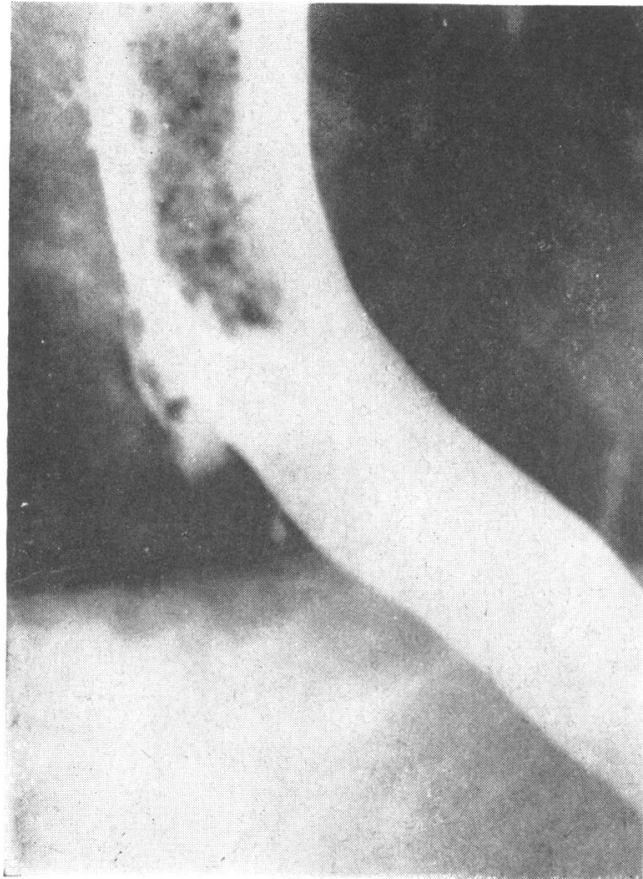

FIG. 1

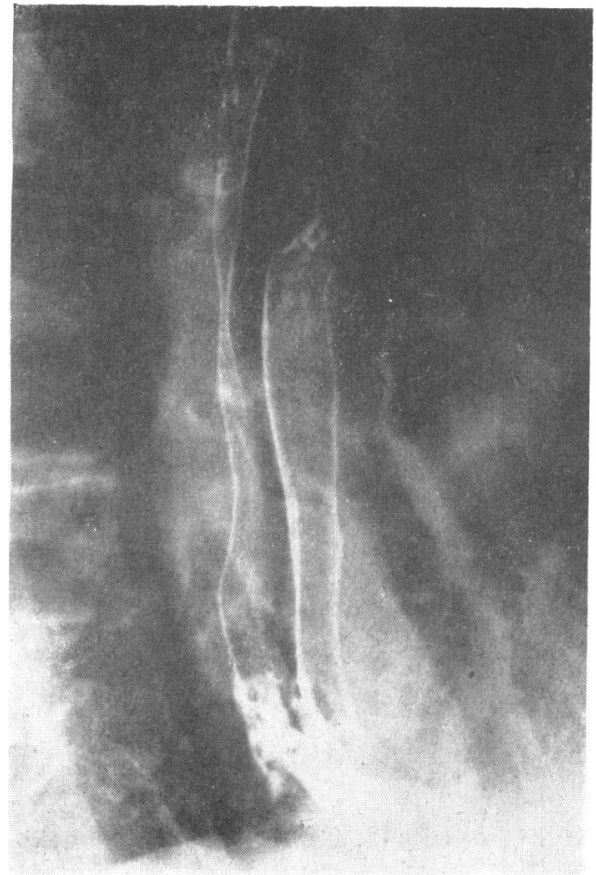

FIG. 2 


\title{
TRIC Agent as a Cause of Neonatal Eye Sepsis
}

\author{
PETER G. WATSON,* F.R.C.S.; DOUGLAS GAIRDNER, † D.M., F.R.C.P.
}

[With Special Plate facing Page 525]

Brit. med. J., 1968, 3, 527-52s

Cummary: Among 2,700 babies born in a maternity hospital there were $71(2.6 \%)$ cases of eye sepsis, mbstly mild. Forty-four of these cases were screened for inclusions of TRIC agent. Four certain positives and $a$ further four very suggestive cases were foundan incidence of $18 \%$ of the cases of eye sepsis investigated. The true incidence is probably somewhat higher.

Follow-up showed that even minimal and transitory eye sepsis from TRIC infection in the neonate can lead to permanent scarring of the conjunctiva and cornea, with or without pannus.

\section{Introduction}

An abacterial form of ophthalmia neonatorum (neonatal conjunctivitis) was recognized as early as 1884 by Kroner. In 1909 inclusion bodies similar to those of trachoma were found in the conjunctival epithelium of these cases, to which the term inclusion blennorrhoea " became applied (Lindner 1909a, 1909b, 1910). The final proof that this condition was due to an organism, the same as or very similar to that which causes trachoma, came when Jones, Collier, and Smith (1959) isolated the causal organism, now named TRIC (trachoma or inclusion conjunctivitis) agent, from the eye of a baby with neonatal inclusion blennorrhoea and from the cervix of the mother of such a baby. In 1960 a series of 38 babies suffering from ophthalmia neonatorum due to TRIC agent was studied at Moorfields Eye Hospital in London by Freedman et al. (1966), who showed that the disease might persist beyond three months, or might recur after treatment; also that scarring of the conjunctiva and/or pannus occurred in some cases. This was in contradiction to the widely held view that the neonatal disease runs a benign course. There is now ample evidence that the usual source of infection in these cases is the mother's birth canal, and evidence of TRIC infection, if sought, is often found in the cervix uteri (Jones, 1964).

Conjunctival exudate ("sticky eye") is common in the first week or two after birth; it is currently seen in about 2-3\% of infants born at the Cambridge Maternity Hospital, an incidence which is probably typical of other maternity hospitals in this country. We have sought to ascertain what proportion of these cases are due to infection with TRIC agent.

\section{Material and Methods}

About 2,000 babies are born annually in the Cambridge Maternity Hospital, which serves a population with a fairly high socio-economic standard. Some $75 \%$ of the mothers and their babies stay in hospital for about 10 days after the birth, and the remaining $25 \%$ for only about two days. There is also a special care unit where premature babies may stay for up to six weeks.

- Eye Surgeon, Addenbrooke's Hospital, Cambridge. + Paediatrician, Cambridge Maternity Hospital.
Any baby showing exudate from the eye, however slight, was noted. Bacterial cultures were taken, and it was intended to examine conjunctival scrapings for inclusion in all cases, but this was eventually achieved in only about $70 \%$ of the series, mainly because the exudate was often transient and cleared spontaneously within 24 to 48 hours.

Scrapings were made as follows. The conjunctiva was anaesthetized with a mixture of $1 \%$ amethocaine and $1 / 10,000$ adrenaline; the latter was added to reduce the number of red cells in the scrapings. When the conjunctiva was blanched each lid was everted in turn and scraped firmly on the tarsal surface with a spatula made from a piece of aluminium welding rod, flattened at the end and roughened. The material so obtained was laid on a slide and allowed to dry in air.

The slides were examined by two independent laboratories for cytoplasmic inclusion bodies of the HalberstaedterProwazek type (Special Plate, Figs. 1 and 2) by the method of Gilkes, Smith, and Sowa (1958). If typical inclusion bodies were seen the slide was reported as "positive." In addition, the cytology was examined, Giemsa-May-Grünwald stain being used. The typical cytology in TRIC infection shows degenerative epithelial cells, numerous polymorphs and lymphocytes, with some macrophages and plasma cells (Special Plate, Fig. 2) (Jones et al., 1959).

If cytoplasmic bodies were seen which lacked the typical regular horseshoe shape of the Halberstaedter-Prowazek inclusions, but where the cytology conformed to that found in TRIC infection as described above, then the slide was reported as "very suggestive" (Special Plate, Fig. 3). A typical cytology without any suggestive inclusions was regarded as negative. The average time for examination of each slide was 25 minutes.

\section{Resuits}

The survey was carried out during the 15 months from March 1966 to June 1967, when 2,700 babies were born in the hospital. A total of 71 babies $(2.6 \%)$ developed exudate from one or both eyes, of which 63 were examined bacteriologically. Conjunctival scrapings from 44 were examined for inclusions; of these, four were positive and four were "very suggestive" (as already defined). In a further four cases the cytology was suggestive but inclusions could not be identified; these cases are not included in the table of TRIC-positive cases.

Bacterial culture in the four TRIC-positive and four "very suggestive" cases gave variable results. In five cases cultures were either sterile or grew only a few colonies of diphtheroids or micrococci, and in three there was a moderate growth of coliforms or diphtheroids (see Table). Onset of symptoms was within the first eight days in seven of the eight cases, and on day 14 in the remaining case, a premature baby. Clinically there was little to distinguish the cases we have regarded as due to TRIC infection. Local inflammation or lid-swelling was negligible; exudate was often scanty and not obviously purulent. 
Details of 8 Cases of Neonatal Conjunctivitis with Inclusions

\begin{tabular}{|c|c|c|c|c|c|c|c|c|}
\hline $\begin{array}{l}\text { Case } \\
\text { No. }\end{array}$ & $\begin{array}{c}\text { Birth Weight } \\
\text { (kg.) }\end{array}$ & $\begin{array}{l}\text { Mother's Married } \\
\text { Status }\end{array}$ & $\begin{array}{l}\text { Age of Onset of } \\
\text { Symptoms (Days) }\end{array}$ & $\begin{array}{c}\text { Unilateral of } \\
\text { Bilateral }\end{array}$ & $\begin{array}{c}\text { Age of TRIC } \\
\text { Sample }\end{array}$ & Inclusions & $\begin{array}{l}\text { Bacterial } \\
\text { Culture }\end{array}$ & Follow-up \\
\hline $\begin{array}{l}1 \\
2\end{array}$ & $\begin{array}{l}3 \cdot 4 \\
2 \cdot 1\end{array}$ & $\begin{array}{l}\text { Unmarried } \\
\text { Unmarried }\end{array}$ & $\begin{array}{r}7 \\
14\end{array}$ & $\stackrel{\mathbf{B}}{\mathbf{U}}$ & $\begin{array}{r}7 \text { days } \\
14 \text { days }\end{array}$ & + & $\begin{array}{l}\text { Sterile } \\
\text { Few colonies }\end{array}$ & \\
\hline $\begin{array}{l}3 \\
4\end{array}$ & $\begin{array}{l}3 \cdot 2 \\
2 \cdot 6\end{array}$ & $\begin{array}{l}\text { Married } \\
\text { Unmarried }\end{array}$ & $\begin{array}{l}3 \\
8\end{array}$ & $\stackrel{\mathbf{B}}{\mathbf{U}}$ & $\begin{array}{l}9 \text { weeks } \\
9 \text { days }\end{array}$ & + & $\begin{array}{l}\text { E. colit }+ \\
\text { Few colonies }\end{array}$ & At 1 year scarring \\
\hline 5 & $3 \cdot 1$ & Married & 7 & $\mathbf{U}$ & 7 days & $+(?)$ & $\begin{array}{l}\text { micrococcl } \\
\text { Few colonies }\end{array}$ & At 6 months pannus \\
\hline $\begin{array}{l}6 \\
7 \\
8\end{array}$ & $\begin{array}{l}2 \cdot 7 \\
1 \cdot 6 \\
2 \cdot 8\end{array}$ & $\begin{array}{l}\text { Married } \\
\text { Father not husband } \\
\text { Unmarried }\end{array}$ & $\begin{array}{l}4 \\
2 \\
2\end{array}$ & $\underset{U}{U}$ & $\begin{array}{l}4 \text { days } \\
2 \text { days } \\
2 \text { days }\end{array}$ & $\begin{array}{l}+(?) \\
+(?) \\
+(?)\end{array}$ & $\begin{array}{l}\text { diphtheroids } \\
\text { E. coli }+ \\
\text { Sterile } \\
\text { Diphtheroids }++\end{array}$ & $\begin{array}{l}\text { and scarring } \\
\text { At } 3 \text { weeks normal }\end{array}$ \\
\hline
\end{tabular}

For many years the accepted policy at this hospital has been to give no specific treatment to cases of neonatal conjunctivitis, and in the great majority the exudate disappears spontaneously within a few days. The TRIC cases were not noticed to differ in this respect.

Of the three cases which could be followed up, two showed conjunctival "sheet scarring" (Special Plate, Fig. 4) of the type characteristically seen in infants in trachoma-endemic countries; one of them showed continuing and active pannus.

\section{Discussion}

The number of undoubted inclusion-positive cases was 4 out of 44 babies with eye exudate $(9 \%)$; and if the four "very suggestive " cases are added, 8 out of $44(18 \%)$. Zwink (1966), who was conducting a similar study at the same time at the London Hospital, found 17 cases of eye sepsis among 332 newborn babies; scrapings yielded two inclusion-positive cases. Their findings are quite comparable to ours. The true incidence may well be higher than we have shown, in view of the cases which had suggestive cytology but in which we were unable to demonstrate diagnostic inclusions. It is well known that in proved TRIC infections inclusions may be very scanty or even absent, and Case 5, which was regarded as "very suggestive," when followed up at six months showed conjunctival scarring and pannus.

The follow-up of our eight babies was disappointing, mainly because so high a proportion proved to have come from a mother who was unmarried (four cases) or whose husband was not the father of the child (one case). These five cases had left the district and could not be traced. There remained three cases which could be followed up, and they were re-examined from three weeks to six months after birth. One was normal ; the other two showed scarring of the conjunctiva, with the tarsal conjunctiva having become adherent to the bulbar conjunctiva in the lower fornix (Special Plate, Fig. 4); one of these had in addition a continuing and active pannus. These findings resemble those characteristically found in infants in trachoma-endemic countries.

Similar signs were also noted in some of the babies in London with eye sepsis due to TRIC agent who were examined by Freedman et al. (1966). All the children in their series, however, had eye signs severe enough for them to be referred to an eye hospital, whereas our babies had a trivial degree of eye sepsis and would not ordinarily have been investigated; nevertheless progressive disease, severe enough to lead to scarring, was found on follow-up in some children. This suggests that the current assumption that TRIC infection in the neonate is self-limiting and not dangerous to the eye needs to be revised. We know of one case of neonatal ophthalmia (A. B. Moffatt and M. J. Corrigan, personal communication, 1968) where the eye was lost after a panophthalmitis; bacterial culture was sterile and scrapings from the eye and conjunctiva showed large numbers of inclusion bodies. It would seem that there is a spectrum of severity of diseasefrom the form with little discharge and scanty inclusions (as exemplified by the present series); through a more easily recognizable form with profuse purulent exudate, swelling of the lid and more readily detectable inclusions; to the occasional severe fulminating form. All forms, we now conclude, may lead to permanent scarring, with or without pannus.

No systematic treatment was given to our cases in the early stages of the disease, but in view of the later findings the question arises whether the common "sticky eye" seen in neonates should be treated by a drug effective against TRIC agent-for example, $1 \%$ tetracycline eye ointment-especially if follow-up of the baby is going to be difficult.

Neonatal TRIC eye infection resembles gonococcal ophthalmia in that the chain of transmission is male urethritis $\rightarrow$ maternal cervicitis (occasionally leading on to severe pelvic inflammation) $\rightarrow$ neonatal conjunctivitis (Jones, 1964 ; Dunlop, Jones, and Al-Hussaini, 1965). This being so, the marital status of our eight cases (see Table) may be relevant.

We owe a large debt to the following, who were responsible for taking and examining our material: Drs. S. N. Das, A. O. Nadimi, and I. S. Revie, of the Department of Ophthalmology, Addenbrooke's Hospital, Cambridge ; Dr. J. H. Rack and Mrs. J. E. Henson, of the John Bonnett Clinical Laboratories, Addenbrooke's Hospital, Cambridge ; and Dr. I. A. Harper and Dr. J. D. Treharne, of the Institute of Ophthalmology, London University. Professor B. R. Jones's advice has been most valuable.

\section{REFERENCES}

Dunlop, E. M. C., Jones, B. R., and Al-Hussaini, M. K. (1965). Rev. int. Trachome, 42, 14.

Freedman, A., et al. (1966). Trans ophthal. Soc. U.K., 86, 313. Gilkes, M. J., Smith, C. H., and Sowa, J. (1958). Brit. F. Ophthal., 42, 473.

Jones, B. R. (1964). Brit. F. vener. Dis., 40, 3.

Jones, B. R., Collier, L. H., and Smith,

Lindner, K. (1909a). Wien. klin. W schr., 22, 1697

Lindner, K. (1909b). Wien. klin. W schr., 22, 1742 .

Lindner, K. (1910). Wien. klin. W schr., 23, 283.

Zwink, B. (1966). Trans. ophthal. Soc. U.K., 86, 310. 